\title{
Using design elements to meet Back Irregularities fashion challenge via biofinished fabrics
}

\author{
Wafaa A. El -Sayed, Maha M.T. Eladwi , Rehab M. Kotb , Wesam E. Hamoud * \\ Textile and Clothing, Faculty of Women for Arts, Science and Education, \\ Ain Shams University, Cairo, Egypt
}

\begin{abstract}
:
Back Irregularities can impose a number of serious challenges side effects such as protruding abdomen, curved back and uneven shoulders. Nevertheless, finding clothes that fit and are reasonably flattering for those with hunched backs still remains an issue of comfort and an overall sense of well-being. The present study aims to hide and fix the appearance of the physical changes that may be caused by back deformity in order to create the appearance of a straight line from head to toe and direct the eye away from any deformity. By using design elements and accessories which are two important fashion components that can help to achieve this goal. In this study, natural cellulosic fabrics (linen, gabardine and poplin) were biopolished using cellulase enzyme to improve their surface properties and quality (fuzzing and pilling) such as physico-mechanical properties were measured and determined. Additionally, dyeing of finished fabrics was carried out using different classes of reactive dyes. Then, create six designs with alterations in pattern and used biopolished fabrics which dye and tie, hand drawing, patch work, stencil and embroidery to meet Back Irregularities fashion challenge.
\end{abstract}

Key words: Back Irregularities, protruding abdomen, curved back, biopolishing.

\section{Introduction}

Back irregularity is one of many conditions that can affect body shape because of the effects of fractures in the spine. Finding both comfortable and stylish clothes can be a challenge because of the height loss, curvature of the spine and widening of the girth that sometimes accompanies spinal fractures (Tantillo .L, 2016)

Few people have what others might call a perfect figure or fabulous physique. But, when a person's body form is very different from that of others, it may affect one's self-image so much that he or she does not feel at ease when participating in the usual activities of life. Some of this feeling may come from being unable to find fashionable clothes that fit (Fan. J

2004 \& HRH, 2014).

${ }^{*}$ Corresponding author: Wesam El-Sayed. Hamoud, Textile and Clothing depart. , Email:wesamelsayed76@yahoo.com. 
The way that they feel about their bodies can impact on all aspects of their daily life. If they are wearing clothes that fit well and feel comfortable this inevitably helps to boost their confidence and morale. Feeling unhappy about how their body looks can result in low selfesteem and affects many people both emotionally and psychologically. A negative body image is not the experience of everyone with spinal fractures, however it is important to acknowledge the real distress suffered by a significant proportion of those affected and for them to know that they are not alone and there are positive ways to tackle these problems.

(HRH, 2014 \& Stone, J, 2000).

Natural fabrics such as cotton and linen are usually the most comfortable to wear keeping people comfortable in hot weather, and it is likely to cling to the stomach: idealy people who have back deformity need a fabric which will fall nicely over mid-section on their bodies (C.M.carr, 1995)

\subsection{Clothing problems resulting from back irregularity :-}

Everyone's figure deviates in some way from what society determines to be ideal. When the deviation is great, it may affect the individual's self-image so much that he or she does not feel at ease when participating in the usual activities of life. Some of this feeling may stem from not being able to find well-fitting and fashionable clothing. The physical changes that occur with back irregularity can create fashion challenges ( Tantillo. L, 2016 \& Melinda R, 2014) as shown in figure (1)

If women have sustained spinal fractures they may begin to notice that:-

1. Their clothes do not fit in the same way as they used to.

2. The dresses or shirts can poke open at the back of the neck and may also feel tighter across the back.

3. A shortened chest cavity can mean all bought clothes are too long and trousers can end up under the bust line.

4. The loss of the waistline and a protruding tummy can make skirts and trousers pull across the abdomen and hemlines can become uneven.

5. A protruding abdomen causes the front waistband to sit too high above the waist and the hemline to rise in front.

6. Flattening of the lower back and buttocks causes the garment to pull across the buttocks and the back hemline to ride too close to the leg.

7. A protruding abdomen causes pants legs to rise up in the front.

8. Height loss causes skirts and pants to be too long.

9. Drooping of the bust line causes bust darts to ride above the bust. 
10. Rounding of the shoulders causes the garment to pull across the shoulders ( Fan. J, 2004, Jeanie. L, 2015 \& Richard. S, Jenny. U., (2006)

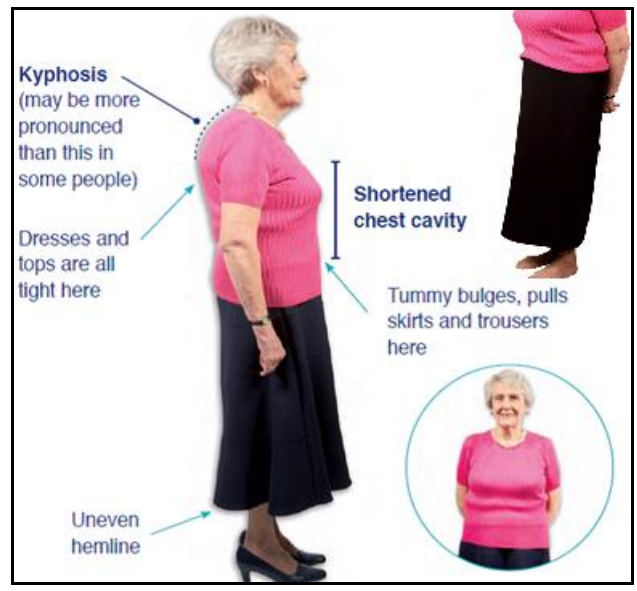

Figure (1) Clothing Problems resulting from back irregularities.

\subsection{Types of spine curvature disorders:}

There are three main types of spine curvature disorders, including as shown in figure (2)

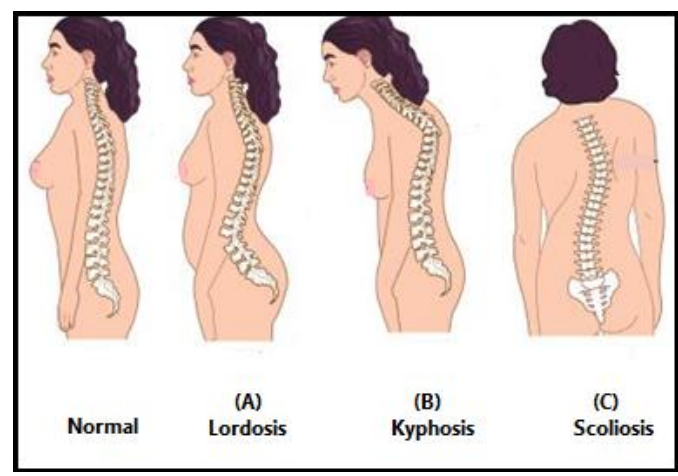

Figure (2) Types of spine curvature disorders.

A. Lordosis also called swayback, the spine of a person with lordosis curves significantly inward at the lower back.

B. Kyphosis which is characterized by an abnormally rounded upper back (more than 50 degrees of curvature).

C. Scoliosis a person with scoliosis has a sideways curve to their spine. The curve is often Sshaped or C-shaped ( Stone, J, 2000 \& Melinda R, 2014)

Depending on the type of spine curvature disorders clothing can be selected in order to create the illusion of a balanced figure. Attention can be drawn away from the figure irregularity by emphasizing another area of the garment (Stacey, F, 2014) 
One can learn to alter patterns and sew clothing to meet individual needs, or one can select ready-to wear garments that have good design features and that can be altered for good fit (Stone, J, 2000, Jeanie L, 2015 \& Wyatt, M, 2014).

\subsection{Bodily Changes resulting from back irregularities:-}

A negative body image is not the experience of everyone with spinal fractures; however it is important to acknowledge the real distress suffered by a significant proportion of those affected and resulted from back irregularities such as:

- Forward projection of the shoulders and head causes the back of the neckline to gape and the front of the neckline to sit close to the base of the throat.

- Bust line droops (chest sags).

- Head and shoulders project forward (due to kyphosis);

- Rib cage rests on pelvis.

- Upper back becomes rounded (kyphosis or dowager's hump) (HRH, 2014, Stone, J, 2000).

\section{Materials and Methods:}

\subsection{Materials:}

$100 \%$ woven cotton and linen fabrics were used [ Viol, Popline, linen and Gabardine ] and their properties that are shown in table (1)

\begin{tabular}{|l|c|c|c|}
\hline \multicolumn{1}{|c|}{ Fabric types } & Weave Structure & Weight $\mathrm{g} / \mathrm{m}^{2}$ & Bleaching \\
\hline Voil & Plain 1/1 & 70 & Half \\
\hline Popline & Plain 1/1 & 103 & Half \\
\hline Linen & Plain 1/1 & 145 & Bleaching \\
\hline Gabardine & Twill 3/1 & 245 & Half \\
\hline
\end{tabular}

Table (1): Fabrics properties.

\subsection{Chemicals:}

Cellulase Enzyme used under the commercial name of Cellumax ${ }^{\circledR}$ AP (prebuffered acidic powder), Hydrogen peroxide, sodium hydroxide, sodium sulphate, sodium carbonate, were used in bleaching process and kindly supplied by DyStar Company, Egypt. The dyes used are Remazol $^{\circledR}$ Yellow 3RS ( C.I.Reactive Yellow176), Remazol ${ }^{\circledR}$ Red 3BS (C.I.Reactive Red239) and Remazol® Blue BB,( C.I.Reactive Blue 220 ) were kindly supplied by DyStar Company, Egypt; and their structure are shown in Table (2). 


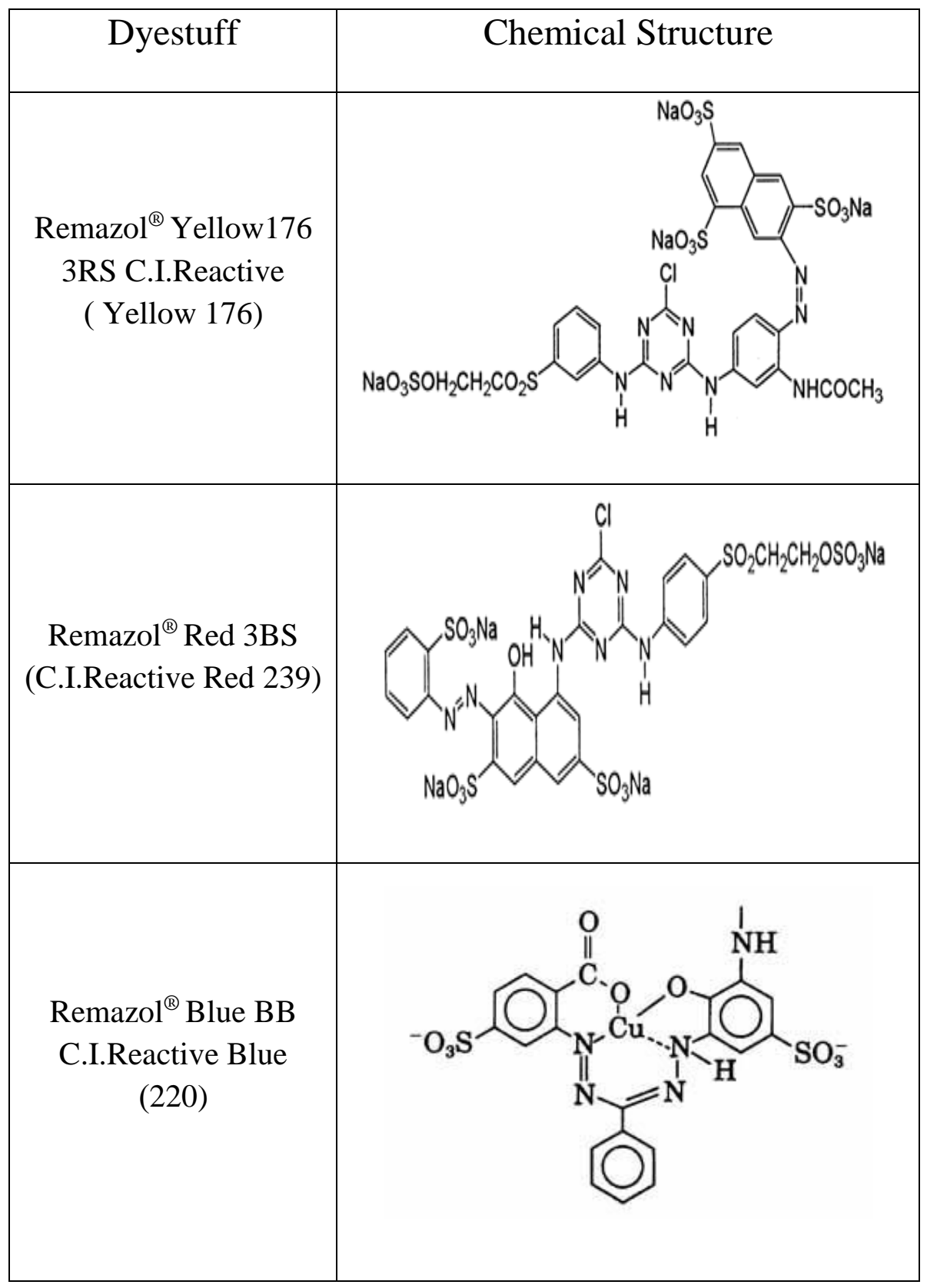

Table (2) Reactive dyes structure.

\subsection{Methods:}

\subsubsection{Fabrics pretreatment:}

Cellulosic fabrics were desized and simultaneously scoured/half bleached with sodium hydroxide (3\%) for 1 hour at $40{ }^{\circ} \mathrm{C}$, followed by bleaching with hydrogen peroxide (35\%) for 1 hour at $90^{\circ} \mathrm{C}$, and finally rinsed several times with top water.

\subsubsection{Biopolishing:}

Biopolishing process was conducted using cellulase enzyme $(2 \mathrm{~g} / \mathrm{l})$ of the enzyme solution at a buffered $\mathrm{pH}$ of $4.5-5$ and at a temperature in the range of $45-60^{\circ} \mathrm{C}$ for $45 \mathrm{~min}$, finally tumble to dry. 


\subsubsection{Reactive dyeing:}

Reactive dyeing of fabrics were carried out using $1 \%$ shade of Remazol ${ }^{\circledR}$ Yellow176 3RS, Remazol ${ }^{\circledR}$ Red 3BS and Remazol ${ }^{\circledR}$ Blue BB and their mixtures according to the manufacture instructions as shown in figure (3).

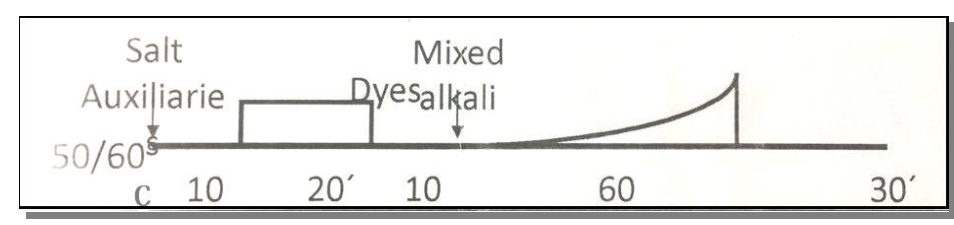

Figure (3): Reactive dyeing procedure were kindly supplied by DyStar Company, Egypt.

\subsection{Test Methods:}

\subsubsection{Physico-mechanical properties:}

Some physico-mechanical properties may be affected by biopoloshing treatment were measured according to standard test method, i.e. Warp and weft sett ( ASTM D 3775 - 98 ); Fabric weight ( ASTM D 3776- 09 a 2013 ); Fabric stiffness (ASTM D1388-96 ); Crease recovery angle of the fabrics (AATCC test method 66-1972); Resistance to tearing ( ASTM procedure D1424-63-1970); Tensile strength and Elongation ( IS 1969(Part2):2010/ISO 13934-2:1999)and Evaluation of Wettability ( AATCC test method, D 39-1980).

\subsubsection{Color strength:}

Color strength (K/S) of the dyed samples was measured on Mini Scan XE Spectrophotometer using Hunter lab Universal Software, which based on Kubelka-Munk equation.

$$
\mathrm{K} / \mathrm{S}=(1-\mathrm{R}) 2 / 2 \mathrm{R}
$$

Where: K, S, and R are the absorption coefficient, scattering coefficient, and reflectance, respectively.

\subsubsection{Wash fastness:}

Color fastness to wash of dyed samples was measured by ISO 105-C06-1994.

\subsubsection{Perspiration fastness:}

Color fastness to perspiration was determined according to AATCC Test Method 15-2002.

\subsubsection{Light fastness:}

Color fastness to light was determined according to AATCC Test Method 16-2004. 


\subsection{Pattern Alterations:}

In order to obtain fit clothing and more comfortable and solve the problems that may occur in clothing by deformity of the spine we should make some alterations in pattern as following:

\section{Alteration in pattern for Dowager hump problem:}

A definite hump on the back pulls the fabric across the high back line; bodice rises up at the back as shown in figure (4). This alteration is very important for all cases of back deformity (lordosis, kyphosis, scolosis) and use it for most designs such as designs $(1,2,3,5,6)$.

Dowager hump

Figure (4): Alteration in pattern for Dowager hump problem.

\section{Alteration in pattern for Sway back problem:}

The back pattern piece needs to be shorter for people with a swayback or very erect posture. Wrinkles that gather at the back waist indicate that the back waist length is too long as shown in figure (5). This alteration is very useful for people with lordosis and kyphosis and use it for skirt and pants in all designs

\begin{tabular}{|c|c|c|}
\hline Sway back & Steps for Alteration \\
\hline alteration in basic pattern & $\begin{array}{l}\text { Trousers or skirt sag just } \\
\text { blew waist. }\end{array}$ \\
$\begin{array}{l}\text { 1. Reduce the 'waist to hip' } \\
\text { length the required } \\
\text { amount at center back }\end{array}$
\end{tabular}

Figure (5): Alteration in pattern for Sway back problem. 


\section{Alteration in pattern for sloping shoulders problem:}

Sloping shoulders cause clothing to bind or folds to form at the underarm as shown in figure.(6) . This alteration used to designs for lordosis and kyphosis cases and use it for designs $(3,5,6)$.

\begin{tabular}{|c|c|c|}
\hline Sloping shoulders & Alteration in basic pattern & $\begin{array}{l}\text { Sag lines appear at the } \\
\text { sides of armscyes. }\end{array}$ \\
1. Slash armscye to nick \\
point as in diagram. \\
2. Overlap required amount \\
3. Lower underarm so that \\
the armscye \\
measurement remains \\
the same, lower balance \\
marks
\end{tabular}

Figure (6): Alteration in pattern for Sloping shoulders problem.

\section{Alteration in pattern for uneven shoulders:}

It is fairly common to have one shoulder lower than the other as shown in figure (7). In this case, make the fitting changes after cutting out the pattern. This alteration used to designs for scolosis case and use this alteration in design (4).

Uneven
shoulders

Figure (7): Alteration in pattern for Uneven shoulders problem. 


\section{Alteration in pattern for large buttocks or abdomen:}

Garment pull across the figure. drag at the crutch in trousers, or a skirt hem will rise at centre back or center front as shown in figure (8). Although hip size is correct the garment may distor because the shape of the figure is uneven. This alteration is very useful for people with lordosis and kyphosis and use it for skirts and pants in all designs.

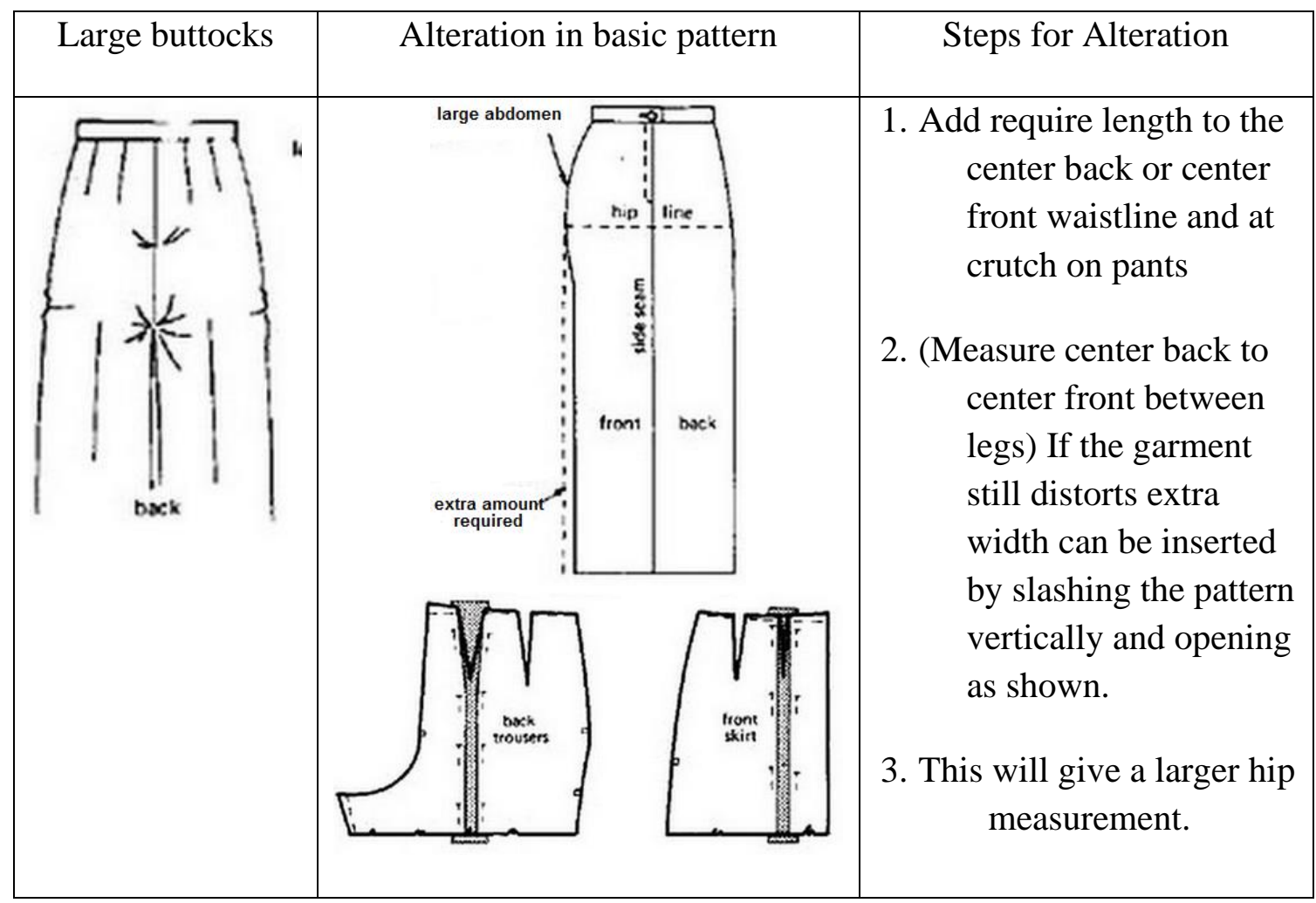

Figure (8): Alteration in pattern for Large Buttocks or Abdomen problem.

\section{Results and Discussions:}

The effect of biopolishing on some physico mechanical properties (fabrics warp and weft sett, weight, stiffness, wettability, tear resistance, crease recovery angles, tensile strength, elongation) were measured and evaluated. As a general observation, it can be seen that there were differences in the obtained results of evaluated properties with respect to different cotton and linen fabrics, which generally may be attributed to surface morphology, fabric construction, weight, as well as inherent strength properties. Since, the mechanical properties of fibers depend on their molecular structure, where macromolecules can be arranged in crystalline and amorphous structure (Mohammad, G, 2015)

\subsection{Effect of biopolishing on fabric warp and weft sett:}

It was observed from the results shown in Figure (9) that, the biopolishing treatment enhanced the fabric set in both directions. There is a significant improvement in gabardine more than poplin and linen, which may be that due to cellulase enzymatic treatment improves surface morphology, appearance and handle values. Which indicate that cellulase enzyme plays a dominating role in altering surface morphology of the fibers and alters the 
dimensional stability of the fabrics. Additionally, the obtained results can also be attributed to the high hydrophilicity gained to fabrics upon biopolishing. Saravanan, D, (2013).

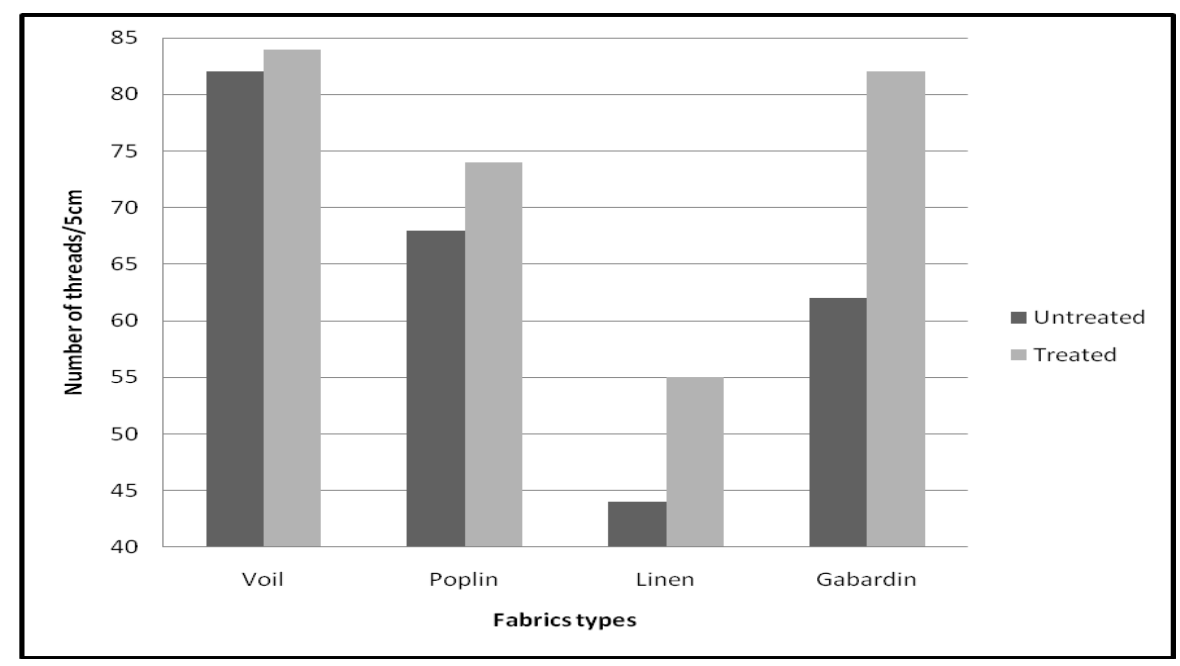

Figure (9): The effect of biofinishing on warp and weft direction set of cotton and linen fabrics.

\subsection{Effect of biopolishing on fabrics weight $\left(\mathrm{g} / \mathrm{m}^{2}\right)$ :}

Figure (10) shows the effect of biopolishing treatment on cotton and linen fabrics weight. It was observed that, the weight of the biopolished samples slightly increased than untreated samples. The weight results are incorrect due to unsimilarity of the weight fabrics, i.e. the fabrics weighted before treatment is not the one after treatments.

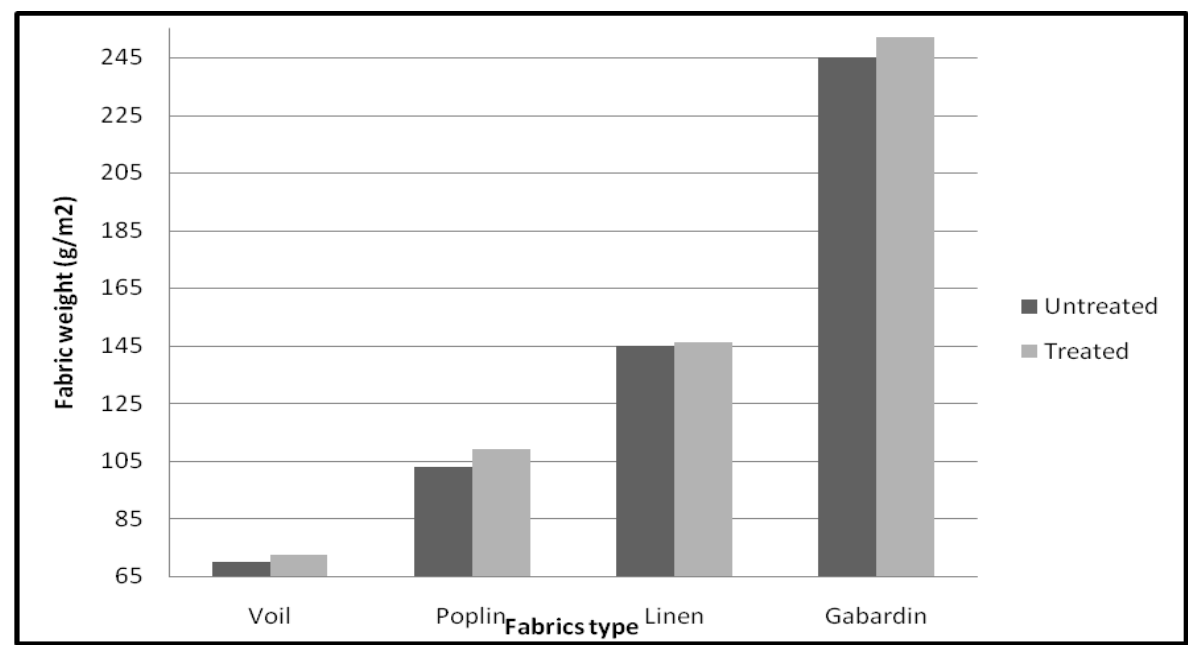

Figure (10): Effect of biopolishing on weight per meter square of cotton and Linen fabrics.

\subsection{Effect of biofinishing on fabrics stiffness:}

It was clearly observed from the data obtained in figure (11) that the stiffness of all types of fabrics used in this study decreased as a result of cellulase enzyme which prevents the fuzz and pills of the fabrics which leading to enhancement after biopolishing treatment in the smoothness and softness. (Saravanan, D, 2009) 


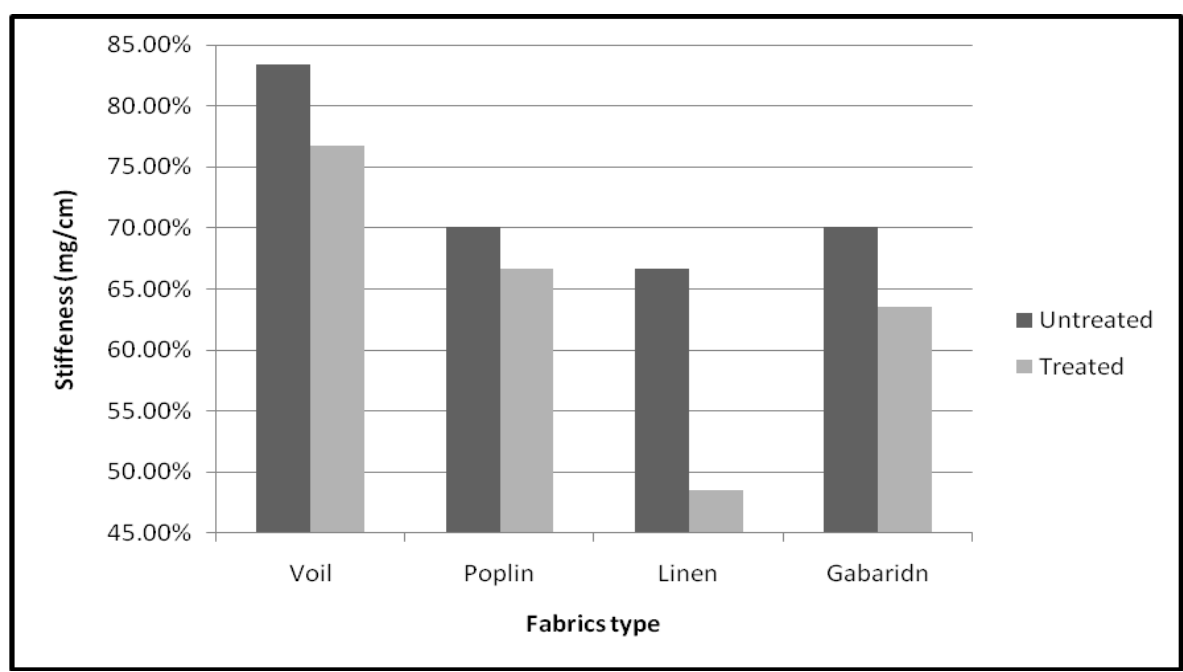

Figure (11): Effect of biopolishing on cotton and linen fabrics stiffness.

\subsection{Effect of biofinishing on fabrics wettability:}

It was clearly observed from the data obtained in figure (12) that the wettability of the fabrics after biopolishing is highly improved depending upon construction of the fabrics, which further improves with softener treatment (Saravanan, D, 2009).

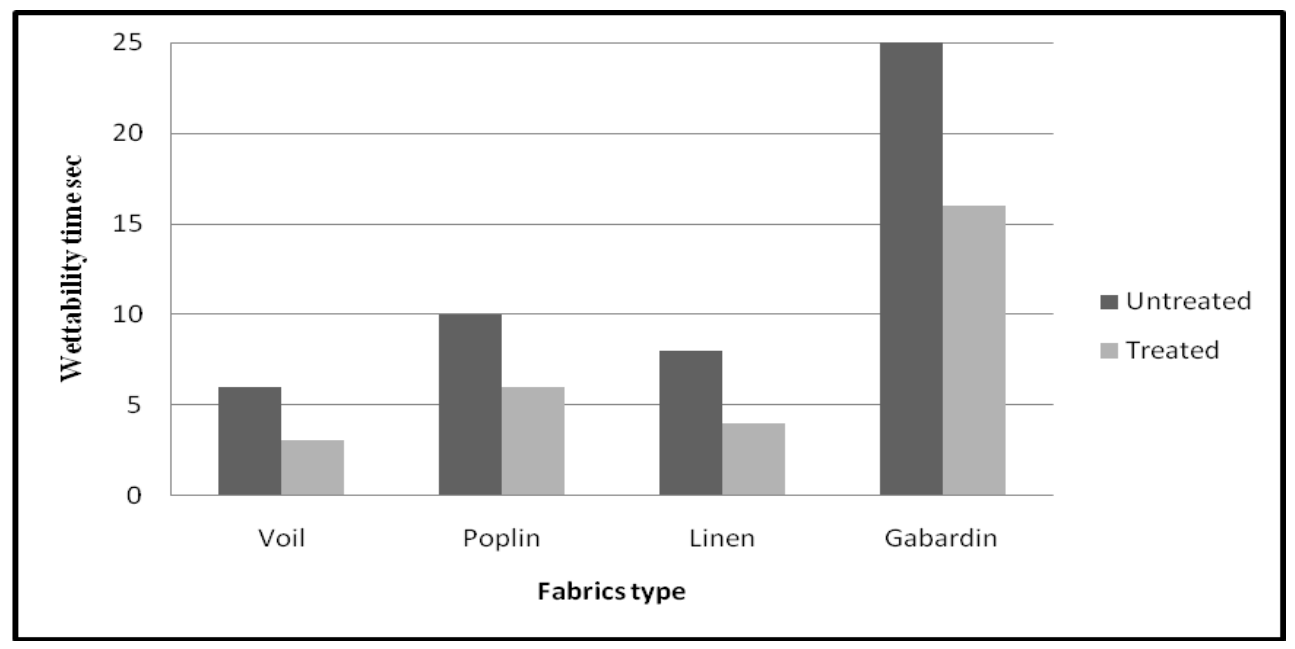

Figure (12): Effect of biopolishing on cotton and linen fabrics wettability.

\subsection{Effect of biopolishing on fabrics tear resistance:}

Figure (13) shows the results of the tear resistance of cotton and linen fabrics which reveald that values decrease in treated samples than the untreated ones. Enzymatic hydrolysis of cotton and linen fibers takes place during biopolishing. This along with the reduced fabric cover values brings about a decrease in the tear strength which indicating the increase of fabric softness. 


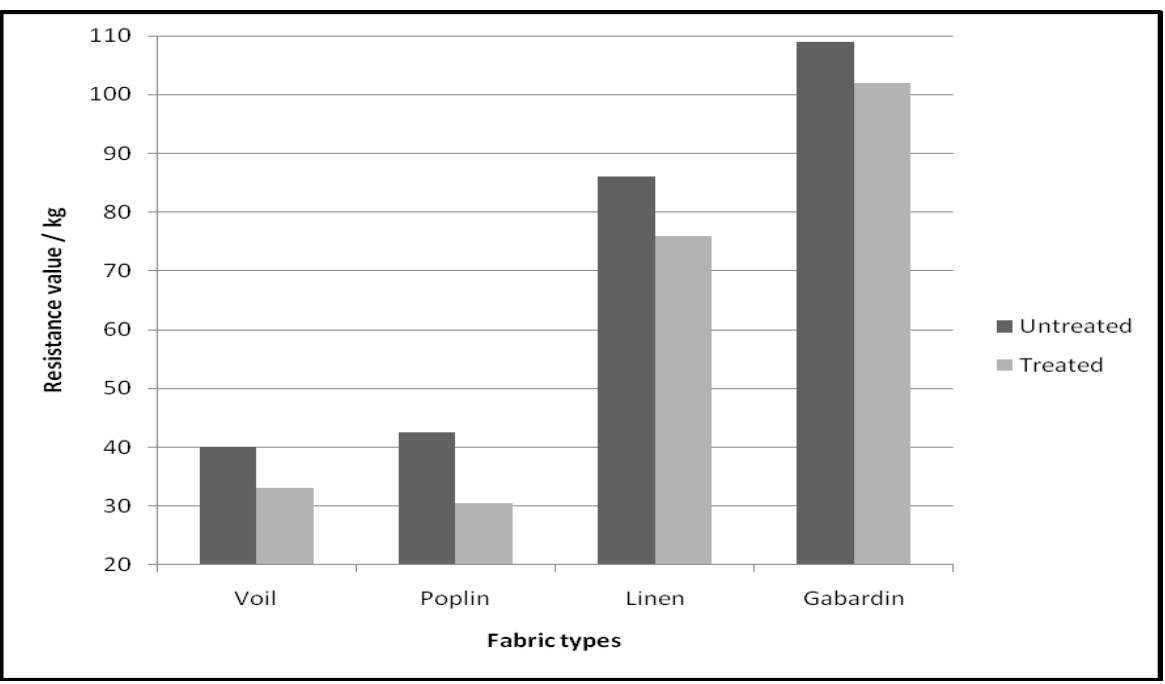

Figure (13): Effect of biopolishing on tear resistance of cotton and linen Fabrics.

\subsection{Effect of biopolishing on fabrics crease recovery angle:}

Figure (14) shows the effect of biopolishing on crease recovery angles, which expressed as fabric resiliency. It can be observed from the data obtained that, the crease recovery angles values of biopolished fabric samples had increased than the untreated ones. The results indicated that the fabrics become less rigid and stiff; easier to stretch and looser in structure, which may be regarded to cellulase enzyme treatment optimize the surface properties (Dixit, S \& Jahan, S, 2012, Doshi, R, \& Shelke, V, 2001)

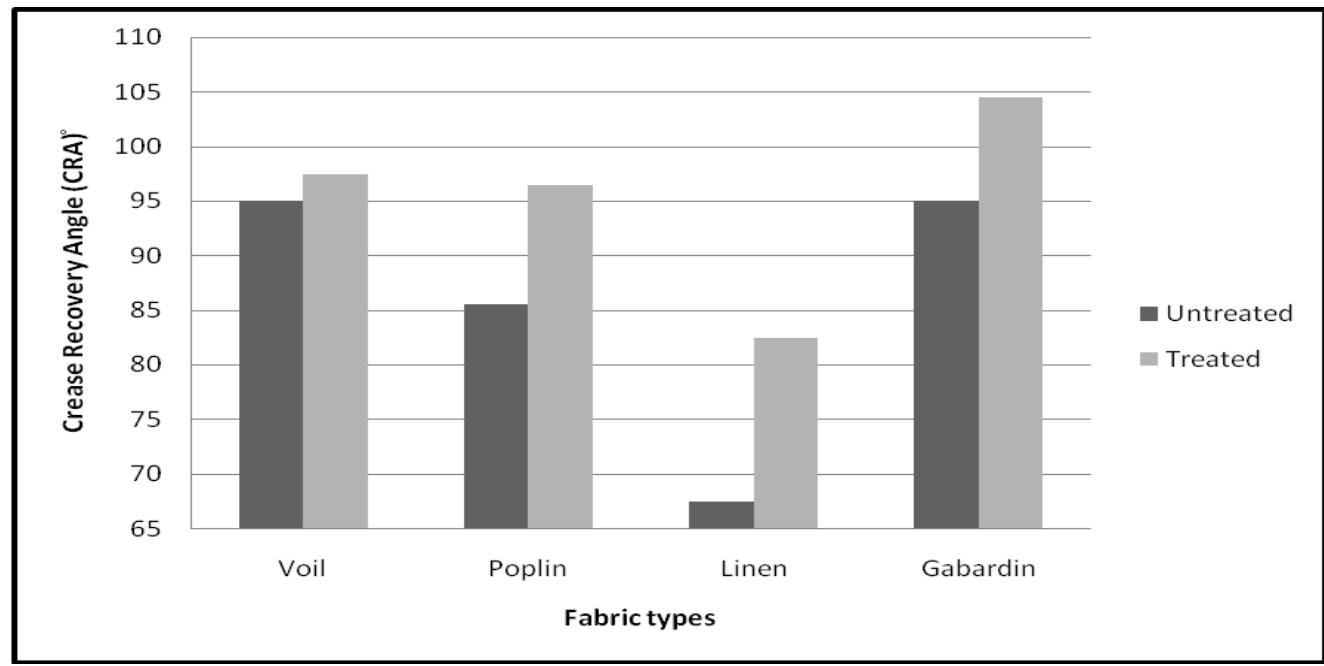

Figure (14): Effect of biopolishing on crease recovery angle of cotton and linen fabrics.

\subsection{Effect of biopolishing on fabrics tensile strength and elongation:}

The effect of biopolishing treatment on tensile strength and elongation of treated fabrics can be obviously seen from the data obtained in figure (15). The results showed that regarded to enzymatic treatment which may be remove projecting fibres, led to improve the texture and appearance of fabrics. This not only creates a smoother fabric with resistance to pilling, but also improves softness, luster and drape (Mohammad, G, 2015) 


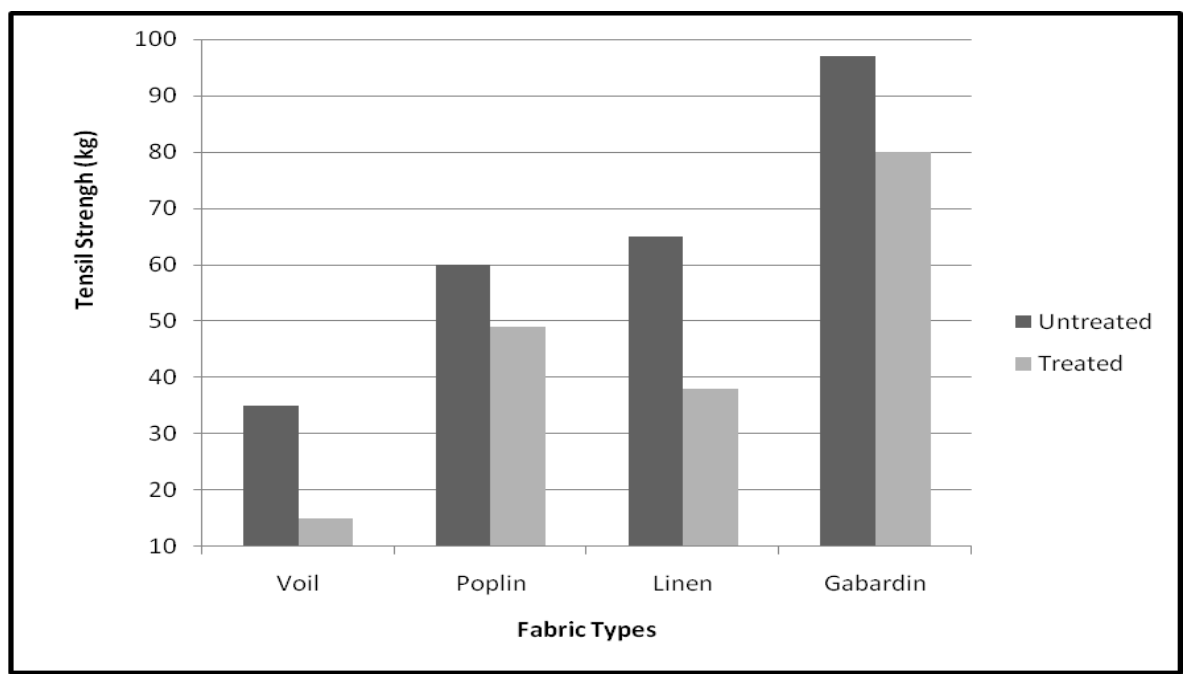

Figure (15): Effect of biopolishing on tensile strength of cotton and linen fabrics.

On the other hand, it can be observed from Figure (16) that the elongation \% of biopolished fabrics were increased. That may be due to enzymatic treatment enhance elongation properties. Biopolishing treatment can be applied to cellulosic fabrics to remove the pills and fuzz from their surface. Hence, reducing the tendency of pilling as well as improving the smoothness, drape, flexibility and luster (Saravanan, D, 2009)

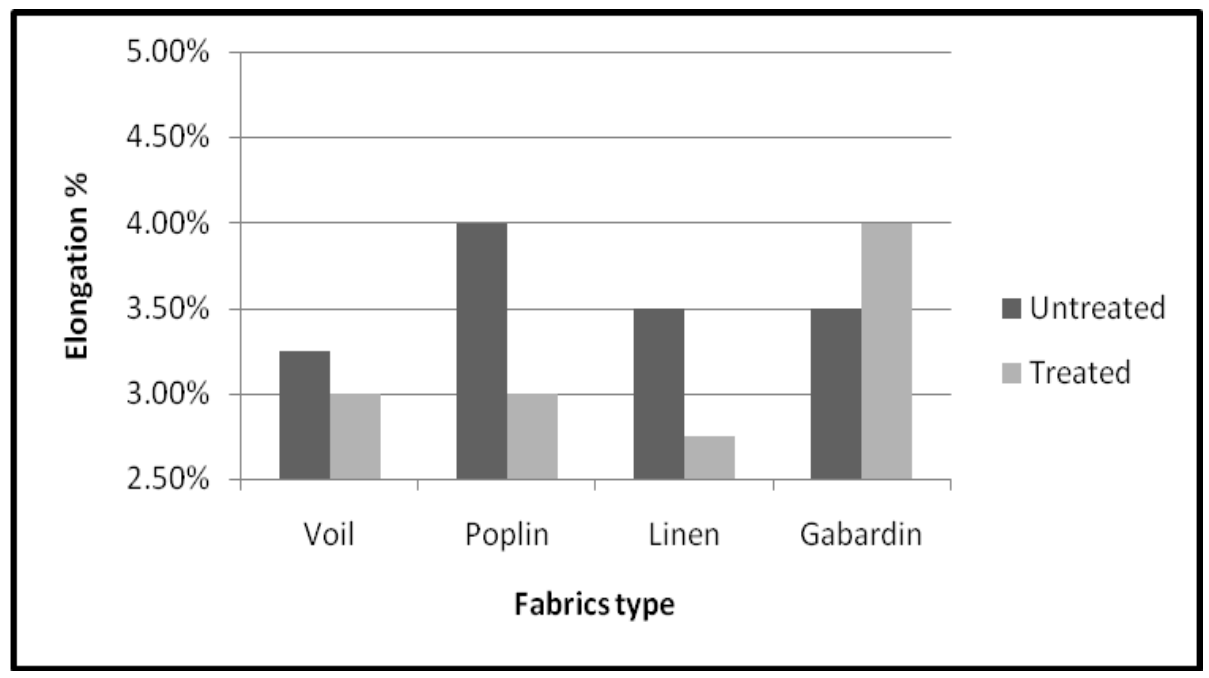

Figure (16): Effect of biopolishing on elongation of cotton and linen fabrics.

\subsection{Reactive dyeing of biopolished fabrics:}

After the application of different classes of reactive dyes, The results of the color strength $(\mathrm{K} / \mathrm{S})$ of dyed fabrics after cellulase treatment are represented in Figures $(17,18,19)$ and clearly showed the positive impact of biopolishing treatment on K/S values, this true for all dyes used in this study. This may be due to the removal of protruding fibers and decreasing the scattering coefficient, which depends on degree of polymerization, ratio of amorphous to crystalline regions, swell-ability, accessibility, chemical reactivity, surface morphology and affinity for dyes (Kan, C \&Law, K, 2012 ; Mohammad, G, 2015) 


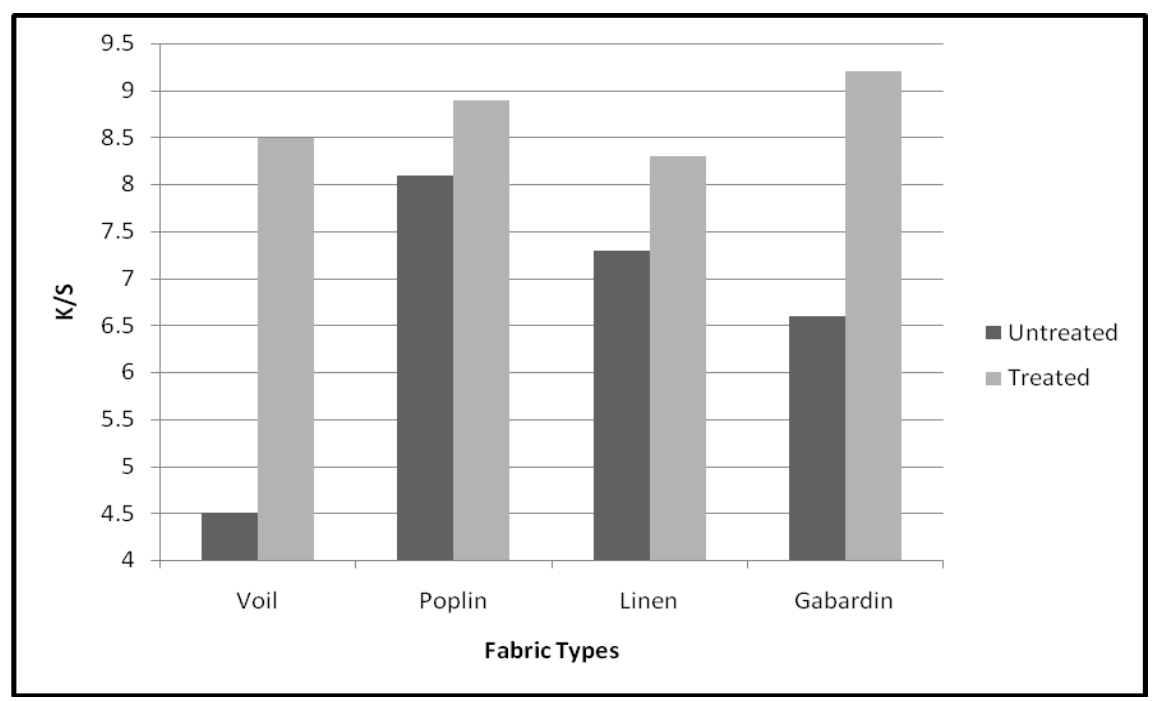

Figure (17): Effect of biopolishing on color strength (K/S) of dyed fabrics using Remazol ${ }^{\circledR}$ Red 239

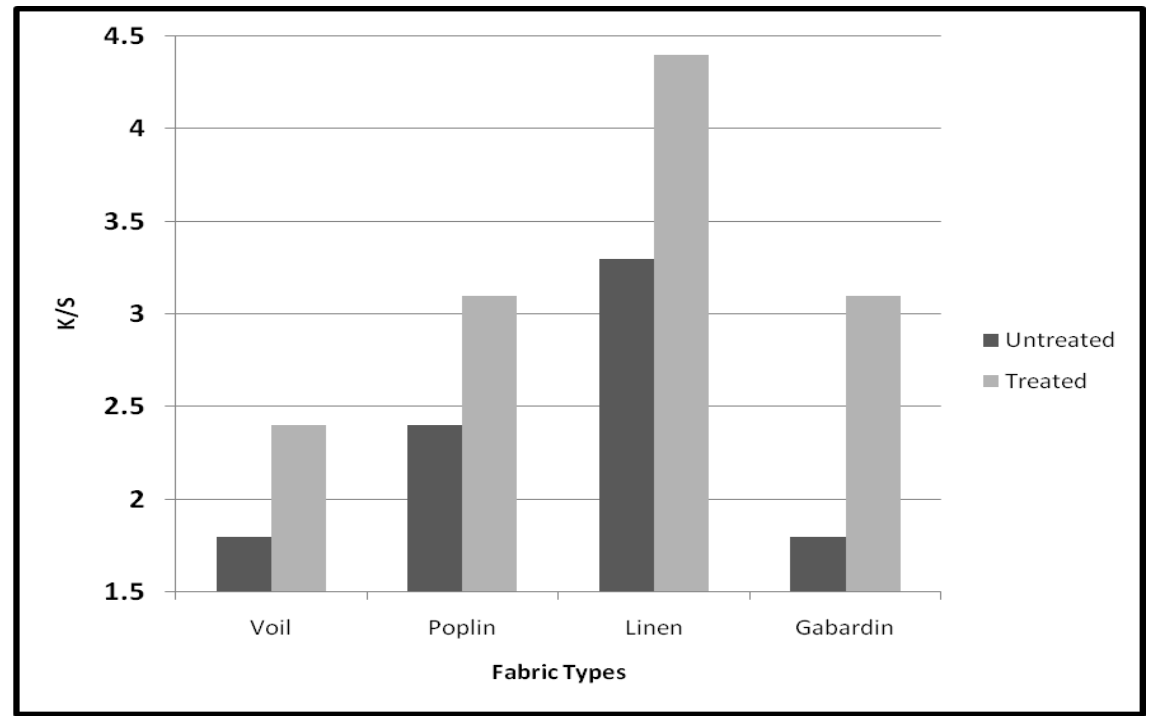

Figure (18): Effect of biopolishing on color strength (K/S) of dyed fabrics using Remazol ${ }^{\circledR}$ Blue 220.

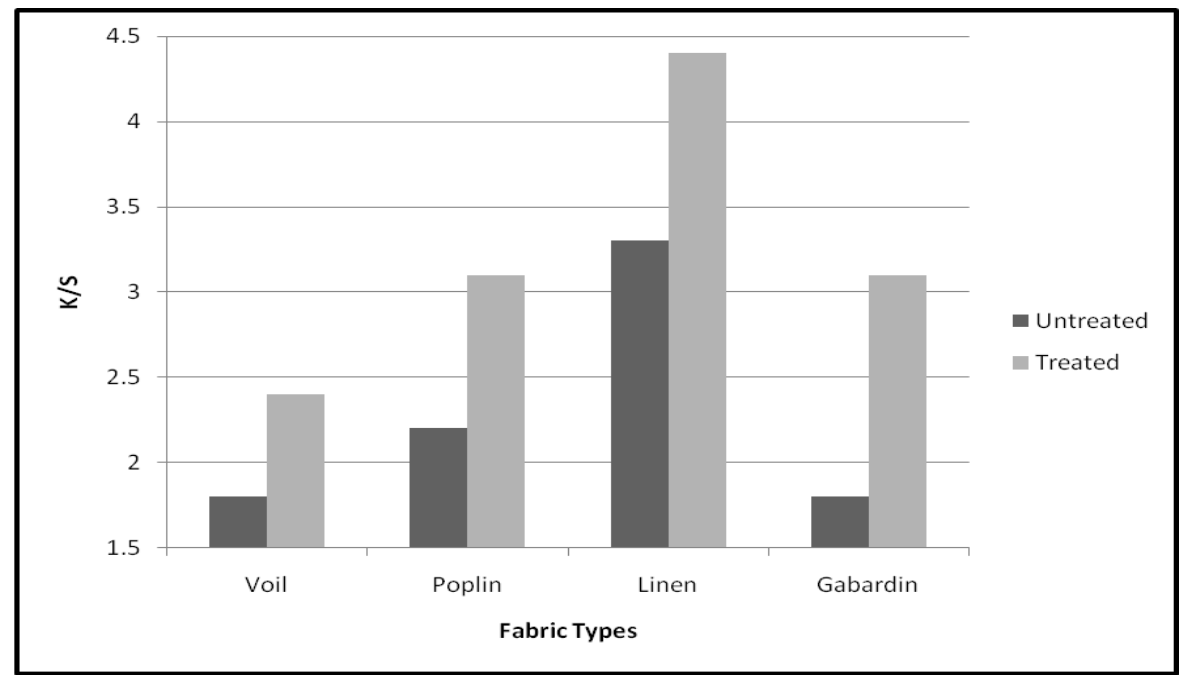

Figure (19): Effect of biopolishing on color strength (K/S) of fabrics using Remazol ${ }^{\circledR}$ Yellow 176. 


\subsection{Fastness Properties:}

The data represented in Table (3) shows the values of light, wash, and perspiration fastness properties of pre- biopolished post dyed gabardine, poplin, voil and linen fabric samples. It can be seen from the obtained results that, all biopolished fabrics acquired better fastness properties regardless dye class and fastness type. it can claimed that biopolishing treatment applied to cellulosic fabrics prior to dyeing process could remove the pills and fuzz from fabric surface that means reducing tendency to pilling, improve the smoothness, drape, flexibility, luster, and fastness properties. Biopolishing using cellulase enzyme give a partial hydrolysis of cellulosic fibers; allowing more available dye sites and penetration that produces more leveling properties (Saravanan, D., 2013).

\begin{tabular}{|c|c|c|c|c|c|c|c|c|c|c|c|c|c|c|c|c|}
\hline \multirow{4}{*}{ Dyed Fabrics } & \multicolumn{4}{|c|}{ Voil } & \multicolumn{4}{|c|}{ Poplin } & \multicolumn{4}{|c|}{ Linen } & \multicolumn{4}{|c|}{ Gabardin } \\
\hline & \multicolumn{16}{|c|}{ Fastness } \\
\hline & \multirow{2}{*}{ 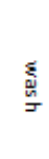 } & \multirow{2}{*}{$\stackrel{\overline{\text { व्: }}}{\exists}$} & \multicolumn{2}{|c|}{ perspiration } & \multirow{2}{*}{ 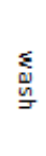 } & \multirow{2}{*}{ 装 } & \multicolumn{2}{|c|}{ perspiration } & \multirow{2}{*}{ ฏ్ّ } & \multirow{2}{*}{$\stackrel{\overline{\bar{g}}}{\exists}$} & \multicolumn{2}{|c|}{ perspiration } & \multirow{2}{*}{ 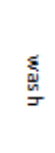 } & \multirow{2}{*}{$\stackrel{\overline{\bar{d}}}{\vec{z}}$} & \multicolumn{2}{|c|}{ perspiration } \\
\hline & & & acidic & alkaline & & & acidic & alkaline & & & acidic & alkaline & & & acidic & alkaline \\
\hline $\begin{array}{l}\text { Untreated / } \\
\text { Yellow } 176\end{array}$ & 3.5 & 5 & 4 & 4 & 3 & 5 & 4 & 4 & 3 & 5 & 4.5 & $4-5$ & 3.5 & $4-5$ & 4.5 & $4-5$ \\
\hline $\begin{array}{l}\text { Treated / } \\
\text { Yellow } 176\end{array}$ & 4 & $5-6$ & $4-5$ & 4.5 & 4 & 6 & 4.5 & $4-5$ & 4 & 6 & $4-5$ & 4.5 & 4 & $5-6$ & $4-5$ & $4-5$ \\
\hline $\begin{array}{l}\text { Untreated/ } \\
\text { Red } 239\end{array}$ & 4 & $2-3$ & 4 & 4 & 4 & 2 & 4 & 4 & 4 & $2-3$ & 4 & 4 & 4 & $2-3$ & 4 & 4 \\
\hline $\begin{array}{c}\text { Treated / Red } \\
239\end{array}$ & 4 & 4 & $4-5$ & $4-5$ & 4 & 3 & $4-5$ & 4 & $5-6$ & 4 & $4-5$ & $4-5$ & 4 & 3 & $4-5$ & $4-5$ \\
\hline $\begin{array}{l}\text { Untreated/ } \\
\text { Blue } 220\end{array}$ & 4 & 2 & 4 & 4 & 4 & $2-3$ & 4 & 4 & 4 & $2-3$ & 4 & 4 & 4 & $2-3$ & 4 & 4 \\
\hline $\begin{array}{c}\text { Treated / Blue } \\
220\end{array}$ & 4 & $2-3$ & 4 & 4 & 4 & $3-4$ & $4-5$ & 4.5 & 4 & 3 & 4.5 & $4-5$ & 4 & $3-4$ & 5 & $4-5$ \\
\hline
\end{tabular}

Table(3) Fastness properties of gabardine, poplin, voil and linen fabrics dyed with different reactive dyes. 


\section{Designs and products:}

\section{Design (1):}

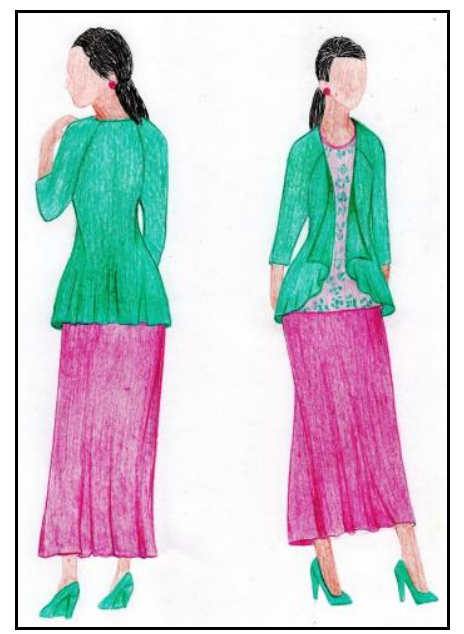

Figure (20): Design (1)

This design is suitable for lordosis and kyphosis cases as shown in figure (20). Its twopiece outfits with raglan sleeves jacket that hang straight rather than being fitted at the waist. These softly-shaped styles have a relaxed fit around the arm hole. This means that they deemphasize rounded shoulders, promote movement and give a softer look and feel to the upper torso and it has also flat-shaped collars as well as using biopolished linen fabric which has more increase in Crease recovery angle than untreated linen fabric $\left(67.5^{\circ}: 82.5^{\circ}\right)$ due to the enzymatic treatment with cellulase enzyme. This treatment improves softness and drape that has a very effective and suitable for almost all figures and physiques in hiding some figure irregularities and helping to full fill our goals.

Full straight skirt with combination of elastic waistband and zipper which comfortable in wearing and can accommodate changes in the figure such as large buttocks or abdomen.

\section{Product (1):}

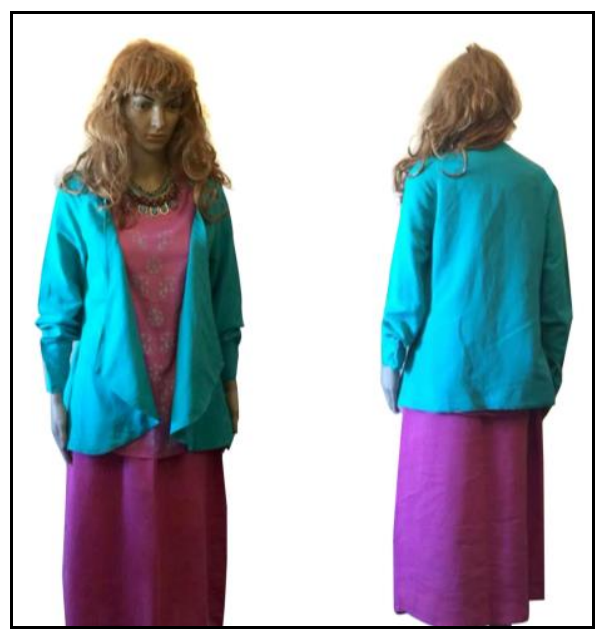

Figure (21): product (1). 
Fabrics: $\quad$ Linen for jacket and skirt and voil for top.

Techniques: Stencil printing in top.

Dyes: $\quad$ Remazol $^{\circledR}($ Yellow 3RS , Green 6B, Red 3BS, Blue BB).

Alterations Alteration for Dowager hump in jacket and top.

in pattern:

Alteration for sway back in skirt.

Alteration for Large Buttocks.

\section{Design (2):}

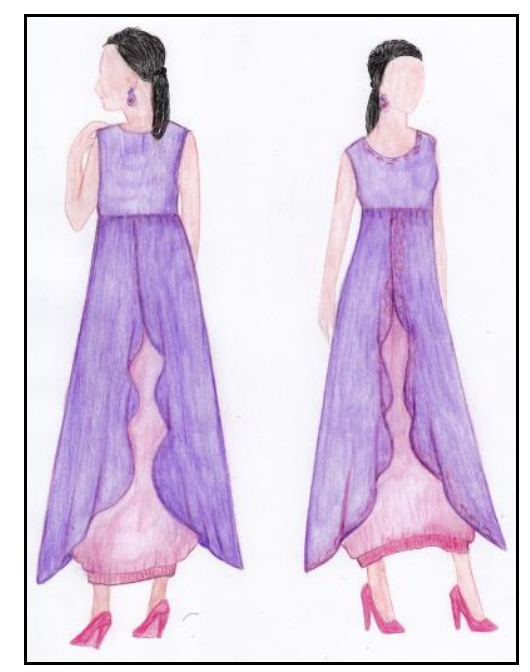

Figure (22): Design (2)

This design is suitable for all cases (lordosis, kyphosis and scolosis) as shown in figure (22). It has empire style (high waist) flared dress with unstitched pleats to creat visual balance between top and bottom torso, and medium-weight biopolished fabrics with more good properties such as flexibility, softening and drapable due to the enzymatic treatment helping to conceal body curves by draw aye away from any deformity The dress has beautiful creative reliefs and decorative layers, which fit loosely and can hide problem areas such as protruding abdomen, sloping shoulders and curved back. The dress has elastic hem in order to solve uneven hem. 


\section{Product (2):}

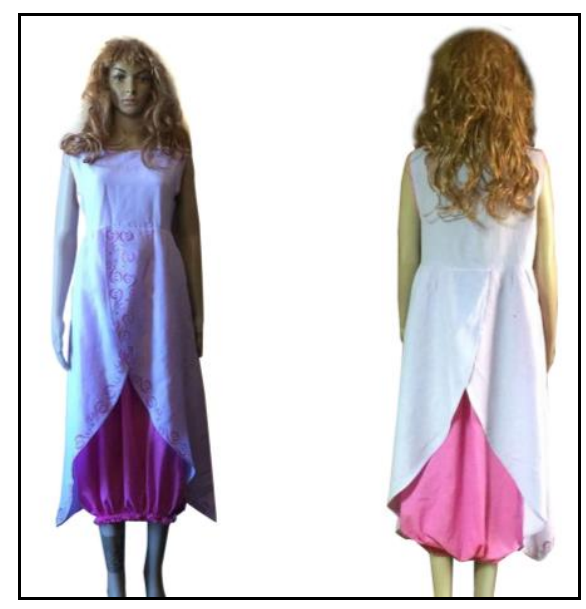

Figure (23): product (2).

Fabrics: $\quad$ Linen and voil for dress.

Techniques: Stencil printing on the two layers of the dress.

Dyes: $\quad \operatorname{Remazol}^{\circledR}($ 6B, Red 3BS, Blue BB).

Alterations Alteration for Dowager hump.

in pattern:

Alteration for Sloping shoulders.

\section{Design (3):}

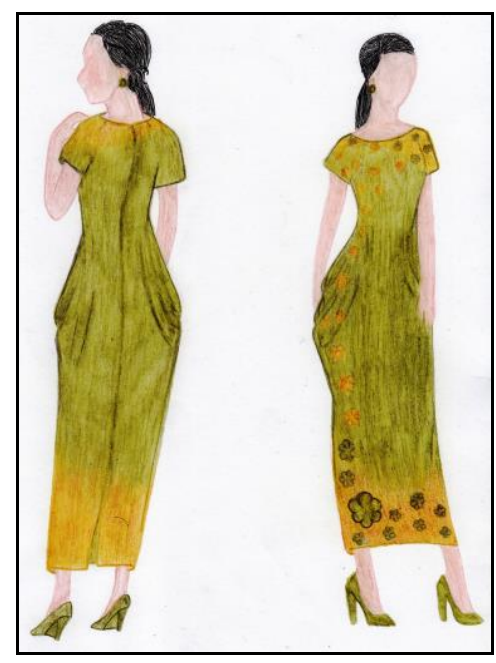

Figure (24): design (3)

This design is suitable for lordosis and kyphosis case as shown in figure (24) The dress has kimono sleeves which minimize fitting problems in order to provide softness and add fullness, without emphasizing bust and curved back. It can be altered easily if a deeper seam is needed over the low shoulder and also provide more comfortable than a set-in sleeve. The dress has A line style which create slimmer look using vertical lines to draw eyes up and down rather 
than across body and it has medium-weight fabrics to shape around curves without emphasizing body contours and it is dyed with dye and tie technique and printed with decorative flowers to draw away from any curves of the body shape.

\section{Product (3):}

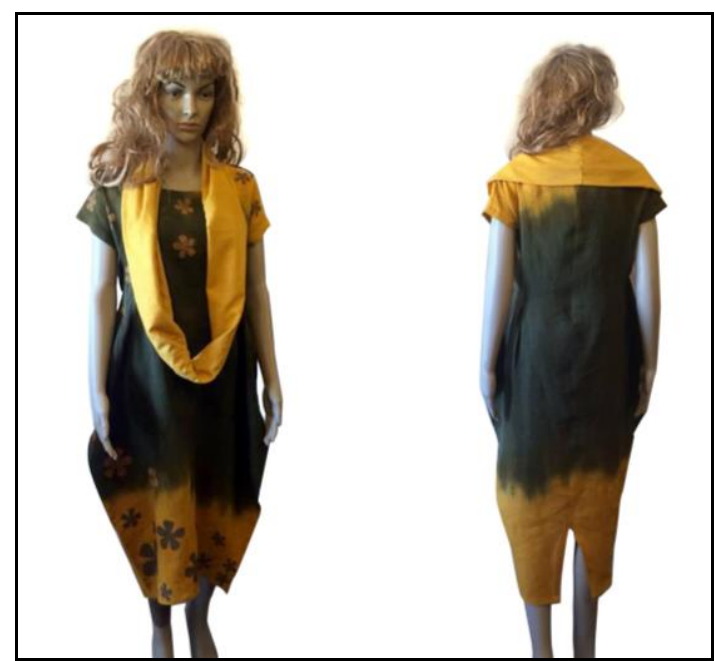

Figure (25): product (3).

Fabrics: $\quad$ Linen for dress and Voil for scarf.

Techniques: Stencil printing on the top and the bottom of dress.

Tie and dye on the dress.

Dyes: $\quad$ Remazol $^{\circledR}$ ( Yellow 3RS, Red 3BS, Blue BB).

Alterations Alteration for Dowager hump.

in pattern: Alteration for Sloping shoulders.

\section{Design (4):}

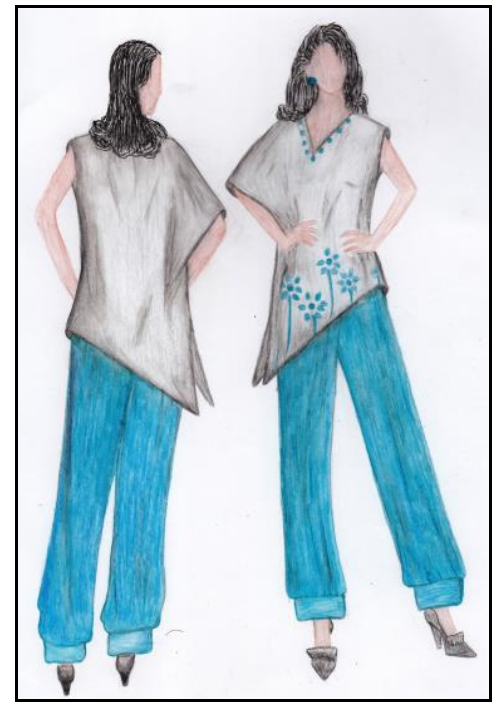

Figure (26): design (4) 
Fabrics: $\quad$ Linen for all parts of dress and vest.

Techniques: $\quad$ Tie and dye on dress.

Embroidery with wooden beads on jacket.

Dyes: $\quad$ Remazol $^{\circledR}$ ( Yellow 3RS, Red 3BS, Blue BB).

Alterations Alteration for Dowager hump.

in pattern:

Alteration for Sloping shoulders.

This design is suitable for all cases (lordosis , kyphosis , scoliosis) as shown in figure (26) Two-piece outfits with floral front blouse, slight $\mathrm{V}$ neckline with decorative trims around the neckline to visually draw attention away from any deformity. This sleeveless style will divert attention from rounding shoulders or a protruding abdomen with fashionable touch and stitched with decorative flowers to mix and match with elastic waistband pants to provide more extra space of garment to de-emphasize large buttocks or abdomen and it has a cuff at the bottom of the pant in order to solve uneven hem if it found.

\section{Product (4):}

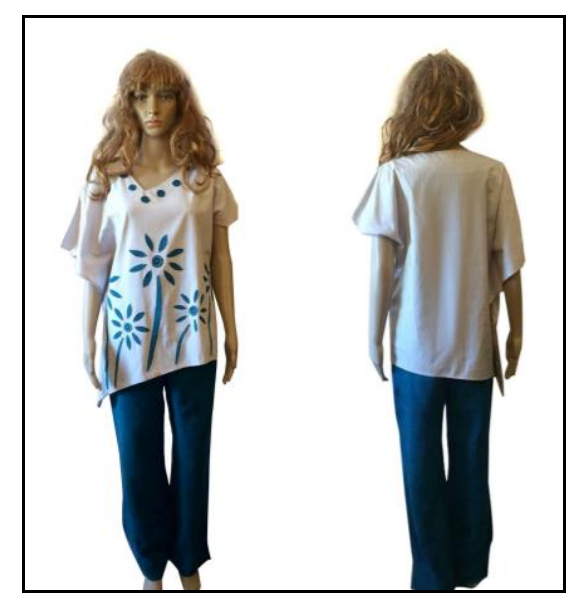

Figure (27): product (4).

Fabrics: $\quad$ Popline for blouse and Linen for pants.

Patch work on blouse.

Techniques: Embroidery stitches.

Dyes: $\quad$ Remazol $^{\circledR}$ ( Yellow 3RS, Red 3BS, Blue BB).

Alterations Alteration for Uneven shoulders.

in pattern: Alteration for Large buttocks.

Alteration for Sway back.

\section{Design (5):}




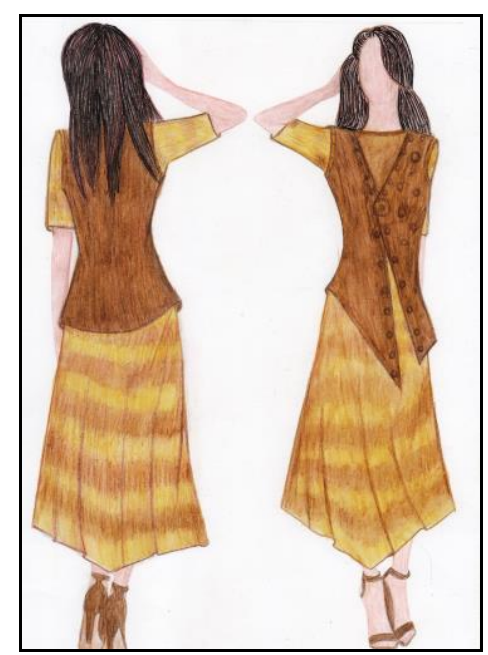

Figure (28): design (5)

This design is suitable for lordosis and kyphosis as shown in figure (28). It has A style dress with half sleeves and dyed with mixed shades of the same color by tie and dye technique and dye the vest with one color which is more darker than the dress for hide any curves and more slimming effect as well as using biopolished fabric which has improve the smoothness, drape, flexibility, luster, and fastness properties due to enzymatic treatment helping to achieve the goal of this study. The bottom of dress has an asymmetrical design in order to work well if drooping hemline are a problem. The vest also designed with an asymmetrical lines and decorative with wooden beads to draw eye away from large abdomen and make the alteration for dowager hump and sloping shoulders.

\section{Product (5):}
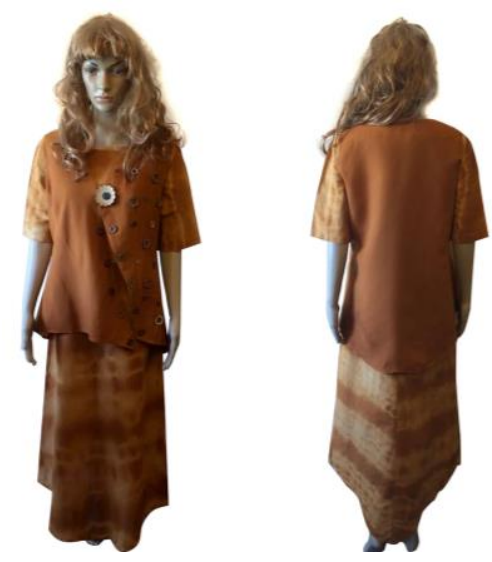

Figure (29): product (5). 


\section{Design (6):}

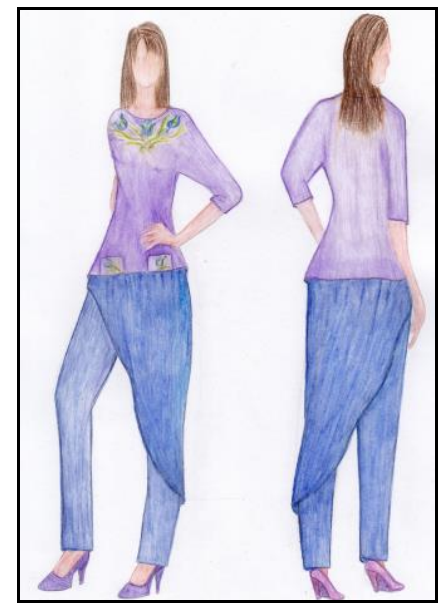

Figure (30): design (6)

This design is suitable for lordosio and kyphosis due to its simplest design. The blouse with raglan sleeves that hang straight rather than being fitted at the waist which provide relaxed fit around the arm hole and decorative with hand drawing technique on the top of blouse and pockets with bright colors in order to create illusions and draw the eye away from any deformity. The pants with combination of elastic waistband and zipper which is more comfortable at wearing and can accommodate large buttocks or abdomen. The pants has layers on front and back in order to hide any protruding of abdomen as shown in figure (30), and make alterations for sloping shoulders, dowager hump and sway back.

\section{Product (6):}

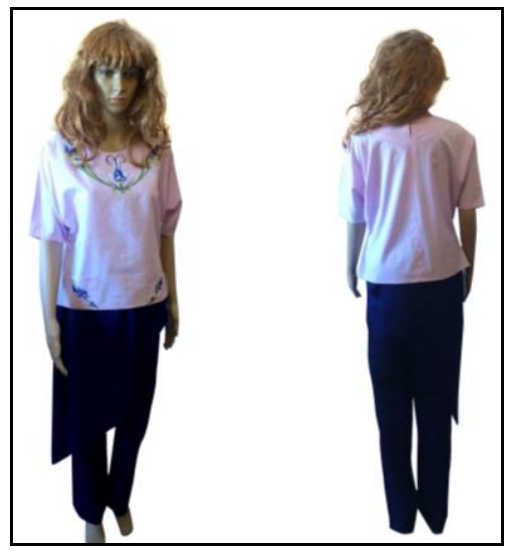

Figure (31): product (6).

Fabrics: $\quad$ Poplin for blouse and Linen for pants.

Techniques: Hand drawing decorative design on blouse.

Dyes: $\quad \operatorname{Remazol}^{\circledR}(\operatorname{Red} 3 B S$, Blue BB). 
Alterations Alteration for Dowager hump.

in pattern:

Alteration for Sloping shoulders.

Alteration for Large Buttocks.

Alteration for Sway Back.

\section{Conclusion}

It is important to find nice-looking clothes that fit well when somone have any type of bake irregularities. Whatever the type of irregularity, clothing can be selected in order to create the illusion of a balanced figure. Attention can be drawn away from the figure irregularity by emphasizing another area of the garment. Biopolish finishing gives flexibility, softening, drapable and reducing pilling propensity to the fabric helping to solve the problems of back deformity by enhance and improve the properties of natural fabrics due to enzymatic treatment.

Finding both comfortable and stylish clothes can be a challenge because of the height loss, curvature of the spine and widening of the girth that sometimes accompanies spinal fractures. By using enzymatic finishing combined whit design elements and accessories we able to create the appearance of a straight line from head to toe and to direct the eye away from any deformity in order to meet the fashion challenge caused by back irregularities. 


\section{References:}

C.M. CARR, Chemistry of textiles industry, First edition ; Blackie Academic \& Professional, London (1995).

Dixit, S, \& Jahan, S. Optimization of the pre-treatment process with acid cellulase enzyme to improve physical properties of cotton fabric. International Journal of Home Economics, 5(2), 130-139, (2012).

Doshi, R, \& Shelke, V. Enzymes in textile industry-an environment friendly approach. Indian Journal of Fiber \& Textile Research, 26, 202-205, (2001).

Fan, W. Yu and L. Hunter, Clothing appearance and fit: Science and technology, (J. Fan, W. Yu and L. Hunter, Clothing appearance and fit: Science and technology 2004

HRH., Clothing, body image and osteoporosis, National Osteoporosis Society,( 2014), https://www.nos.org.uk/health-professionals/ /document.doc?id=805

Janis S, Clothing ideas for people with back irregularities, Iowa State University, Ames, ( 2000).

Jeanie L. D, Living With Osteoporosis, Bone Loss and Posture: 6 Tips to Look Your Best, WebMD, LLC,(2015)

Kan C. and Law K., A Study of Reactive Dyeing and Enzymatic Treatment on Some Properties of Cotton. International Conference. Textiles \& Fashion. Bangkok Thailand. 3-4,( 2012)

Lila de Tantillo., Clothes for Osteoporosis Patients. Remedy Health Media, LLC,(2016), http://www.healthcentral.com/osteoporosis/c/9487/24310/clothes/

Melinda R, DO, MS., Types Of Spine Curvature Disorders. WebMD,LLC, (2014), http://www.webmd.com/back-pain/guide/types-of-spine-curvature-disorders

Michael L, MD., Clinical Research \& Osteoporosis Newsletter, A Publication of New Mexico Clinical Research \& Osteoporosis Center, (2005)

Mohammad G. U., Effects of biopolishing on the quality of cotton fabrics using acid and neutral cellulases, Uddin Textiles and Clothing Sustainability, (2015).

Richard S \& Jenny U., Fundamental of fashion design, First edition, AVA Publishing SA, United Kingdom ,(2006) .

Rudd, N, \& Lennon, S. J., Body Image and Appearance Management Behaviors in College Women. Clothing and Textiles Research Journal, (2000). 
Saravanan D., Lakshmi S. N., Senthil R.K. and Vasanthi N.S., Biopolishing of Cotton Fabric with Fungual Cellulase and its Effect on the Morphology of Cotton Fibers. Indian J. Fiber and textile Res. 38(2): 156- 160,(2013).

Saravanan D., Vasanthi N.S. and Ramachandran T., A Review on Influential Behavior of Biopolishing on Dyeability and Certain Physico-mechanical Properties of Cotton Fabrics. Carbohydrate Polymers. 76(1): 1-7,(2009)

Stacey F,. How to Look Your Best With Osteoporosis, Health Monitor Network.( 2014)

Wyatt M,. Osteoporosis and Body Image, Everyday Health Media, LLC.( 2014), http://www.everydayhealth.com/osteoporosis/osteoporosis-and-self-esteem.aspx 


\section{الملخص باللغة العربية}

إستخدام عناصر التصميم لمواجهة تحديات الموضه لعيوب الظهر بإستخدام أقمشه معالجه حيويا وفاء السيد أنور , مها محمدى طه العدوى , رحاب محمود قطب , وسام السيد حمود , قسم اقتصاد منزلى , كلية البنات للآداب و العلوم و التربية , جامعة عين شمس, القاهرة ,, ج.م.ع الملخص : 20 (المص

فى هذه الدر اسة تم استخدام عناصر التصميم من خط ولون وخامه وذللك لعمل تصميمات مناسبه

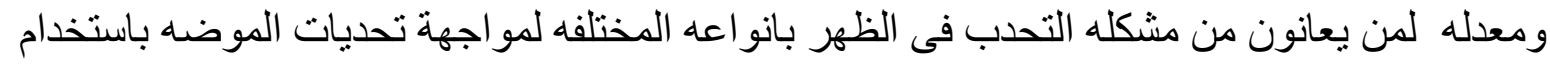
اقمشه القطن و الكتان بعد تجهيز ها بيولوجيا بو اسطه انزيم السليلويز بغرض هن تحسين التهين الاداء و المظهريه

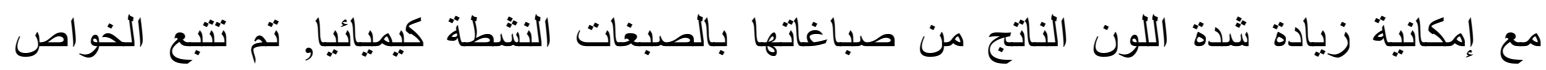
الفيزوميكانيكية للأقمشة محل الدر اسة (المجهزة حيويا و المصبو غة ) وكذلك قياس شدة اللون للاقششة المصبو غة. 